\title{
Bovine paratuberculosis in Puerto Rican dairy herds and its association with selected performance parameters ${ }^{1}$
}

\author{
José Pantoja ${ }^{2}$, Bernardo Vallejo ${ }^{2}$ and José Acosta ${ }^{3}$
}

J. Agric. Univ. P.R. 94(3-4):247-254 (2010)

\begin{abstract}
A random sample of herds and cows within herds was used to determine the prevalence of Mycobacterium avium ssp. paratuberculosis (MAP) infection in Puerto Rico. The sample included only adult lactating or non-lactating animals on the sampling date. The number of samples per herd varied from 25 to 150 , according to herd size (25 in her ds with fewer than 150 cows or $25 \%$ of the larger herds) for a total of $2,053 \mathrm{co}$ ws in 28 her ds. All adult animals (241) of the two herds of the University of Puerto Rico were sampled in order to compare the prevalence of MAP in these herds relative to the prevalence in the herds where only a sample of the animals was evaluated. The diagnosis of MAP was based on the ELISA seologic test of blood samples, according to the manufacturer's instructions, and the results were categorized as positive or negative. On the basis of the serologic test, the prevalence of MAP in herds and cows was 96.00 and $5.77 \%$, respectively. No difference in the latter criterion was detected between the herds in which all the adult animals were tested and those where only $25 \%$ of the animals were tested (5.39 vs. $5.87 \%$, respectively). The cows with positive ELISA test for MAP had numerically lower daily milk yield $(17.64 \mathrm{~kg})$ and yield adjusted to $305 \mathrm{da}$ ys $(5,489 \mathrm{~kg})$, and significantly higher somatic cell counts $(1,262,000$ cells per milliliter) than those negative to the test (with respective values of 18.33 and $5,894 \mathrm{~kg}$ and 288,000 cells per milliliter)
\end{abstract}

Key words: paratuberculosis, ELISA, prevalence, milk production

\section{RESUMEN}

Paratuberculosis en hatos lecheros de Puerto Rico y su relación con parámetros de desempeño animal

Se utilizó una muestra al azar de hatos y vacas dentro de hatos para determinar la frecuencia de inf ección con Mycobacterium avium ssp. paratuberculosis (MAP) en Puerto Rico. El muestreo incluyó solamente animales adultos, secos o en or deño al momento del m uestreo. El número de muestras por hato varió desde 25 hasta 150 , de acuerdo al tamaño del mismo (25 en hatos de menos de $\mathbf{1 5 0}$ animales, o el $25 \%$ de los animales en hatos de mayor tamaño) para un total de 2,053 v acas en 28 hatos. Se tomaron muestras de todos los animales adultos (241) de los dos hatos lecheros de la Universidad de Puerto Rico con el propósito de comparar la frecuencia de MAP determinada en estos hatos relativo a la frecuencia en los hatos privados en los que sólo se e valuó una muestra. El diagnóstico de MAP se realizó me-

${ }^{1}$ Manuscript submitted to Editorial Board 22 September 2010.

${ }^{2}$ College of Agricultural Sciences, University of Puerto Rico, Mayagüez Campus.

${ }^{3}$ Veterinary Division, United States Department of Agriculture. 


\begin{abstract}
diante la prueba serológica ELISA en muestras de sangre, según las instrucciones del fabricante, y los resultados se catalogar on como positivos o negativos. Basado en la prueba serológica, la frecuencia porcentual de MAP en los hatos y en las $v$ acas dentro del hato fue de $96.00 \%$ y $5.77 \%$, respectivamente. No se detectaron diferencias en este segundo criterio entre los hatos donde todos los animales se incluyeron en el muestreo y aquéllos donde el muestreo fue de sólo el $25 \%$ de los animales adultos $(5.39$ vs. $5.87 \%$, respectivamente). Las vacas que arrojaron pruebas ELISA positivas a MAP tuvieron valores de producción de leche diaria $(17.64 \mathrm{~kg})$ y ajustada a 305 días $(5,489$ $\mathrm{kg}$ ) numéricamente menores y recuentos de células somáticas significativamente mayores $(1,262,000$ células por mililitr o) que las que arr ojaron una prueba negativa (con respectivos valores de $18.33 \mathrm{~kg} ; 5,894 \mathrm{~kg}$; y 288,000 células por mililitro).
\end{abstract}

Palabras clave: paratuberculosis, ELISA, frecuencia, producción de leche

\title{
INTRODUCTION
}

Paratuberculosis or Johnes disease is a chronic progressive disease mainly of ruminants, characterized by intestinal infection, caused by Mycobacterium avium ssp. paratuberculosis (MAP). The primary route of infection is by ingestion of milk, water or feed contaminated with feces from animals shedding MAP (CAST, 2001). Although most animals are infected at a very early stage of life, the onset of clinical signs is delayed for several years, and is normally evident at an average age close to five years, the age that coincides with the second or third lactation. In cattle and other ruminants Johnes disease causes persistent scours, weight loss and gradual wasting until death. This condition is endemic in the USA, where the level of herd infection $\mathrm{w}$ as estimated at $22 \%$ (USDA-APHIS, 1997), causing annual losses of $\$ 178.00$ and $\$ 181.00$ per cow for herds smaller than 50 cows or greater than 500 cows , respectively. The estimated economic losses were mainly due to reduced milk production, impaired reproductive performance, early culling and poor condition at culling with lower salvage value (Tiwari et al., 2007).

The MAP diagnosis is generally by fecal culture, which is the traditional procedure, and more recently by detection of antibodies in blood samples (Clark et al., 2008). Fecal culture has the drawback of a long, expensive and variable incubation period whereas the ELISA method is less expensive and quic ker but less sensitive for detecting infected animals (CAST, 2001; Collins and Soc kett, 1993). The results of the studies to evaluate the effects of subclinical paratuberculosis, detected by ELISA testing on milk production, have been inconsistent, varying from increased yield in infected cows (Johnson et al., 2001) to no significant effect (Hoogendam et al., 2009; McNab et al., 1991) to decreased milk yield in MAP positive cows (Norlund et al., 1996).

The prevalence of paratuberculosis in the dairy industry of Puerto Rico has not been evaluated, despite occasional diagnosis by local vet- 
erinarians, and despite the fact that most herds on the island have imported dairy cattle from the North American mainland. Quantifying the prevalence of this disease and estimating its impact on production under local conditions is necessary to develop cost effective control measures. Because of the inconsistent results in the literature regarding the impact of paratuberculosis on production parameters , this study was designed to evaluate the prevalence of subdinical Johnes infections in herds of Puerto Rico on the basis of serologic ELISA test and its relationship with selected production data obtained from the Dairy Herd Improvement Program.

\section{MATERIALS AND METHODS}

A random sample w as taken from the dairy herds of Puerto Rico stratified by region. Only adult cows in lactation or dry in number proportional to the herd size ( $25 \%$ of the animals), were selected and sampled between August 2004 and Marc h 2005. Also, all adult animals (241) of the two herds of the University of Puerto Rico were sampled in order to compare the prevalence of MAP detected in these herds with that of the herds in which only $25 \%$ of the animals were sampled.MAP diagnosis was based on the serologic USDA-licensed absorbed ELISA test of blood samples by calculating the ratio of reaction of a given sample relative to that of a known positive oneThe blood samples were collected from the coccigeal vein of the animals into serum collection tubes and maintained on ice until delivered the same day to the Puerto Rico Department of Agriculture Agrologic Laboratory to be centrifuged. Data relative to productive performance during the lactation in course at sampling were obtained electronically from the Dairy Herd Improvement Program; the data included cow identification, days open during current lactation, and milk somatic cell count for the test day closest to the date of sampling.

The relationships between the ELISA test results and the inc luded performance variables were established by use of the CHI SQUARE test (SAS Institute, 2004). Significant probabilities are referred to $\mathrm{P}<0.05$.

\section{RESULTS AND DISCUSSION}

Twenty-eight of the 364 herds in operation on the Island at the time of sampling were included, a number which represents $8 \%$ of the total. The evaluation included 2,053 cows (Table 1), a number which represents $2.0 \%$ of the total adult cow census in Puerto Rico (DAPR, 2006). Based on the results of the serologic ELISA test, the prevalence of MAP in herds of Puerto Rico was 82\%. In 1997 the National Animal Health 
TABLE 1.-Number of observations, average, minimum, maximum and standard error for ELISA test, age at testing, daily milh production, somatic cell count (SCC), days in milk, milk production adjusted to 305 days on a mature equivalent basis and estimated relative producing ability of the cows.

\begin{tabular}{lcrrrr}
\hline Variable & Number of observations & Average & Minimum & Maximum & Standard deviation \\
\hline ELISA $^{1}$ & 2,053 & 0.0764 & 0.00 & 3.14 & 0.23 \\
Age, months & 1,290 & 60.75 & 21.00 & 176.00 & 27.98 \\
Average daily milk production, $\mathrm{kg}$ & 943 & 20.00 & 5.44 & 42.18 & 6.65 \\
SCC, cells $\mathrm{ml}$ & 841 & 573.84 & 13.00 & $9,052.00$ & $1,144.67$ \\
Days in milk & 1,294 & 287.00 & 17.00 & 850.00 & 143.19 \\
Average 305 days milk production, $\mathrm{kg}$ & 535 & $5,831.83$ & $2,263.42$ & $1,100.97$ & $1,353.97$ \\
Estimated relative producing ability, $\mathrm{kg}$ & 535 & 185.71 & $1,839.77$ & $2,404.94$ & 665.87 \\
\hline
\end{tabular}

${ }^{1}$ Expressed as the ratio of reaction of the evaluated simple relative to a positive, varies from zero to four. 
Monitoring System of the US Department of Agriculture reported that $22 \%$ of the US operations were Johnes positive (USDA-APHIS, 1997). In that study, a Johnes positive dairy operation was defined as a herd in which at least two cows tested positive for MAP antibodies, or one cow tested positive to MAP and at least $5 \%$ of the cull cows had exhibited symptoms of Johnes disease during the previous 12 months. The present data do not include any information on previous cull cows, but twenty-three of the herds evaluated had at least two positive animals on the basis of the ELISA test. Based on the serologic test, the prevalence of paratuberculosis was estimated as $17 \%$ in the state of Florida (Braun et al., 1990) and 50\% in those herds of Wisconsin (Collins et al., 1994). The higher herd MAP prevalence in Puerto Rico may be due in part to the fact that no systematic testing or treatment for this condition is practiced locally.

On a cow basis, prevalence of MAP was $5.77 \%$, a percentage which is comparable with the findings of Collins et al. (1994; 7.29\%) and Norlund et al. $(1996 ; 10 \%)$ from the state of Wisconsin using serologic testing, but lower than that reported from a recent study of dairy herds in Michigan (Johnson et al., 2001). No difference $(P>0.05) \mathrm{w}$ as detected between the results from two herds that were totally sampled and those in whic $\mathrm{h} 25 \%$ of the cows were randomly sampled (5.39 vs $5.87 \%$ ), all of which indicates that a random sample of animals was adequate for evaluating the prevalence of MAP in the whole population.

The average values of age, daily milk production, test day somatic cell count, and milk production adjusted to 305 days at the time of sampling were 61 months, $17.86 \mathrm{~kg}, 574,000$ cells $/ \mathrm{ml}$, and 5,832 $\mathrm{kg}$ of milk, respectively (Table 1 ). These results are representative of the universe of dairy cows enrolled in the Dairy Herd Improvement Program in Puerto Rico (DRMS at Raleigh, DHI-202 State Averages, March 2005). The average number of days in milk and the estimated relative producing ability of the cows were both numerically higher in the ELISA-negative cows in relation to those of cows that had a positive reaction (257 vs. 288 days and 233 vs. $390 \mathrm{~kg}$, respectively).

The cows with positive ELISA tests had average daily and adjusted 305-day milk production numerically lower than those cows with negative results (17.64 vs . 18.83 ; and $5,489 \mathrm{vs} .5,894 \mathrm{~kg}$, respectively, Table 2). The present data agree with those of Norlund et al. (1996), who reported a 305-day adjusted milk production that was significantly higher by $376 \mathrm{~kg}$ in MAP negative, in relation to positive reaction cows Others have reported no such effects (Hoogendam et al., 2009) or even reported increased milk production (McNab et al., 1991). Although not reaching statistical significance, the 305 -day adjusted milk production for the ELISA-negative cows was $406 \mathrm{~kg}$ higher than that of the posi- 
TABLE 2.-Least square means for age, daily milk production, somatic cell count, days in milk, milk production adjusted to 305 days on a mature equivalent basis and estimated relative producing ability of the cows.

\begin{tabular}{|c|c|c|c|}
\hline Variable & Positives ELISA & Negatives ELISA & Probability \\
\hline Age, months & 61.94 & 59.27 & 0.55 \\
\hline Daily millk production, kg & 17.64 & 18.33 & 0.64 \\
\hline Somatic cell count, cells $/ \mathrm{ml}$ & 1,269 & 366 & 0.00 \\
\hline Days in milk & 257 & 288 & 0.18 \\
\hline Milk production adjusted to 305 days and mature equivalent, $\mathrm{kg}$ & 5,489 & 5,894 & 0.12 \\
\hline Estimated relative milk producing ability, kg & 233 & 390 & 0.21 \\
\hline
\end{tabular}


tive cows. Under the quota system of milk marketing in Puerto Rico , where the average milk price paid to producers is high, a considerable economic impact of Johnes disease is likely, and justifies the establishment of an effective control program against bovine paratuberculosis.

Milk somatic cell counts for the test da y closest to the blood sampling of the ELISA-negative cows were significantly lower than those of the cows that gave positive results $(\mathrm{P}<0.05)$, all of which is in agreement with the results of $\mathrm{McNab}$ (1991) but not with Norlund et al. (1996), who reported similar somatic cell counts in both positive and negative MAP ELISA-tested animals. If MAP positive animals are at a higher risk of mastitis, the numerically lower milk production observed in this study may be due to this effect. Studies on the association of mastitis with subclinical paratuberculosis have been inconsistent. McNab et al. (1991) reported an increased incidence of mastitis in MAP-positive, whereas Wilson et al. (1993) found a reduction in the incidence of mastitis in subclinically MAP-affected animals.

The findings of this study indicate that the herd incidence of MAP in Puerto Rico is higher than that of the mainland, even though the cow prevalence within herds is similar. Based on the numerically lower adjusted milk production and the significantly higher milk somatic cell count of the MAP positive cows in relation to that of the ones that tested negative, it is evident that this condition has a more important economic effect under local conditions than in the continental USA.

\section{LITERATURE CITED}

Braun, R. K., C. D. Buergelt, R. C. Littel, S. B. Linda and J. R. Simpsom, 1990. Use of an enzyme linked immunosorbent assay to estimate prevalence of paratuberculosis in cattle of Florida. J. Am. Vet. Med.Assoc. 196:1251.

Clark, D. L., J. J. Koziczkowski, R. P. Radeliff, R. A. Carlson and J. L. E. Ellingson, 2008. Detection of Mycobacterium avium paratuberculosis: comparing fecal culture ver sus serum enzyme-linked immunosorbent assay and direct fecal polymerase chain reaction. J. Dairy Sci. 91:2620.

Collins, M. T., D. C. Sockettt, W. J. Goodger, T. A. Conrad, C. B. Thomas and D. J. Carr, 1994. Herd prevalence and geographic distribution of, and risk factors for, bovine paratuberculosis in Wisconsin. J. Am. Vet. Med. Assoc. 204:636.

Collins, M. T. and D. C. Sockett, 1993. Accuracy and economics of the USDA-licensed enzyme-linked immunosorbent assay for paratuberculosis. J. Am. Vet. Med. Assoc. 203:1453.

Council for Agricultural Science and Technology (CAST), 2001. Johnes disease in cattle. Num. 17.

Dairy Record Management System at Raleigh, 2005. DHI-202 State Summary-March 2005.

Department of Agriculture of Puerto Rico (DAPR), 2006. Informe anual año fiscal 20052006. Oficina de la Reglamentación de la Industria Lechera de Puerto Rico.

Hoogendam, K., E. Richardson and J. F. Mee, 2009. Paratuberculosis-sero status and milk production, SCC and calving interval in Irish dairy herds. Irish Vet. J. 62:265. 
Johnson, Y. J., J. B. Kaneene, J. C. Gardiner, J. W. Lloyd, D. J. Sprecher and P. H. Coe, 2001. The effect of subc linical Mycobacterium paratuberculosis infection on milk production in Michigan dairy cows. J. Dairy Sci. 84:2188.

McNab, W. B., A. H. Meek and S. W. Martin, 1991. Associations between dairy production indices and lipoarabinomannan enzyme-immunoassay results for paratuberculosis. Can. Vet. Res. 55:356.

Norlund, K. V., W. J. Goodger, J. Pelletier and M. T. Collins, 1996. Association between subclinical paratuberculosis and milk production, milk components and somatic cell counts in dairy herds. J. Am. Vet. Med.Assoc. 208: 1872.

SAS Institute, 2004. SAS®/STAT. User's Guide. Version 9.00. SAS Institute, Cary, NC, USA.

Tiwari, A., J. A. VanLeeuwen, I. R. Dohoo, G. P. Keefe, J. P. Hadad, H. M. Scott and T. Whiting, 2007. Production effects of pathogens causing bovine leucosis, bovine viral diarrhea, paratuberculosis and neosporosis. J. Dairy Sci. 90:659.

USDA-APHIS, 1997. Johnes disease in U . S. dairy operations . NAHMSUSDA:APHIS:VS,CEAH, Fort Collins, Co. \#N245.1097.

Wilson, D. J., C. Rossiter, H. R. Han and P. M. Sears, 1993. Association of Mycobacterium paratuberculosis infection with reduced mastitis, but with decreased milk production and increased cull rate in clinically normal dairy cows. J. Am. Vet. Res. 54:1851. 